\title{
Effective utilization of an aquatic weed in an eco-friendly treatment of polluted water bodies
}

\author{
*15AVITA DIXIT; ${ }^{2}$ SUCHI TIWARI, \\ ${ }^{2}$ Applied Chemistry Department, Maulana Azad National Institute of Technology, Bhopal, M.P., India \\ Pin-462007 email ID: savitadixit30@yahoo.com \\ ${ }^{2}$ Research Scholar, Chemistry Department, S.N.G.G.P.G., College, Shivaji Nagar, Bhopal, M.P. India. Pin 462016. Email ID: \\ shuchi_tiwari77@yahoo.com
}

\begin{abstract}
World's most troublesome aquatic weed water hyacinth (Eichhornia crassipes) has been studied for its tendency to accumulate the heavy metal contaminants present in water bodies. A thorough chemical investigation has shed light on the fact that it accumulates heavy metals like Lead $(\mathrm{Pb})$, Chromium $(\mathrm{Cr}), \mathrm{Zinc}(\mathrm{Zn})$ and Manganese $(\mathrm{Mn})$ to a large extent. The presence of higher concentration of these metals in the aquatic weed signifies bio-magnification that lead to filtration of metallic ions from polluted water. The concept that water hyacinth can be used as a natural aquatic treatment system in the uptake of heavy metals is explored. @JASEM
\end{abstract}

Metals constitute an important group of environmentally hazardous substances. During this century, many lakes in India have received elevated inputs of heavy metals as a result of an increase in atmospheric deposition and anthropogenic activities around the lakes. The heavy metals when present beyond permissible limits acts as pollutants because, firstly they cannot be destroyed through biological degradation as in the case with most organic pollutants and secondly metals tend to accumulate in the environment especially with bottom sediments of the water body by association with organic and inorganic matter. In aquatic environment metals can be termed as "Conservative pollutants" which are added to the aquatic environment, are there forever and cannot be broken down to harmless substances by bacterial action as many organic pollutants are.

The discharge of heavy metals in the environment has several obvious impacts on aquatic ecosystems. There may be an increase in residue levels in water, sediments and dependent biotic components like fishes, aquatic plants etc., their decreased productivity and increase in exposure of human beings to harmful substances thereby disrupting the ecological balance (Moore 1984). Sometimes, unusually high inputs of toxic trace elements to the aquatic environment have resulted in ecological changes and great financial losses, affected commercial fisheries and in some cases, have been hazardous to human health.

Increasing awareness of ecological hazard of toxic metals from urban and industrial sources have involved considerable interest in the study of levels and fate of heavy metals in the aquatic environment (Ahmed et. al. 2003). Many research regarding heavy metals in aquatic ecosystem has been carried out in different parts of the world. The potential toxic metal elements such as chromium, lead, copper, zinc etc. are identified to cause health hazards in animals (Bryan 1976), (Lowe 1970) and (Sivakumar et. al. 2001). In case of many heavy metal, biomagnification occurs through food chain (Sudhira et. al. 2000). So, it is necessary to know the heavy metal concentration in all the trophic levels as well as sediments.

Aquatic Weed 'Water Hyacinth (Eichhornia crassipes)': Water hyacinth (Eichhornia crassipes) is one of the worst weeds in the world--aquatic or terrestrial (Holm et. al. 1977). It is recognized as a very aggressive species of aquatic plant, which grows very fast and eliminates other aquatic species in its competition. Eichhornia crassipes (Mart.) Solms. is native to Brazil. This aquatic species are thought to have been first introduced into the United States at the 1884 Cotton States Exposition in New Orleans, Louisiana (Sculthorpe 1967). In India, this weed is locally known as "Jal Kumbhi or Samudra Sokh", which literally means "able to dry up the sea". In many places in the world including India, water hyacinth continues to present daunting environmental and economic problems.

Water hyacinth can cover a lake surface from shore to shore. Most of the times it is considered to be a weed that is responsible for choking lakes to death. It is a floating, flowering, perennial weed, form dense rafts in the water and mud. It grows on the surface of the water body, with the shoot system above the water level and roots developing inside water. The roots affect free movement of the aquatic fauna in water, thus hampering fisheries and recreational activities. Moreover, it captures all the excess nutrients present in the water body and prevents it from reaching other aquatic plants.

Water hyacinth, has the unique property to accumulate heavy metals such as cadmium, copper, lead and zinc in the root tissues of the plant 
(Muramoto et.al. 1983) and (Nor 1990). In Hong Kong, water hyacinth has been used for freshwater treatment. Moreover, water hyacinth has been utilized for removal and recovery of silver from industrial wastewater (Pinto et. al. 1987).

Habitat and Growth Characteristics of the Weed: Water hyacinth grows in ponds, canals, freshwater and coastal marshes and lakes. It multiplies by vegetative reproduction, which allows the plant to quickly colonize large areas in relatively short periods of time. Because water hyacinth is freefloating, wind and water currents function to distribute plants within a water body (Tarver et. al. 1986). It grows faster than any other tested plant (Wolverton et.al. 1979); populations can double in as little as 6 days (Mitchell 1976).

Bioaccumulation tendency of water hyacinth: Although heavy metals are essential component of the aquatic ecosystem, which are required for growth of plants, but their higher concentrations are toxic to all life forms. Aquatic macrophytes like water hyacinth absorb these metallic ions and deposit them in different parts of the plant body depending upon their affinity towards that particular metal. Thus, absorption and accumulation mechanism of the macrophytes render the services of cleaning of water body from the heavy metal contamination. The role of macrophytes in limnetic ecosystem cannot be ignored as they acts as natural biofilter and helps in removing the toxic pollutants from water bodies, which are exposed to heavy metal pollution.

There has been use of water hyacinth for removal of nutrients and heavy metals from sewage and sludge ponds (Vietmeyer 1975). It has high affinity for the metals and is used for phytoremediation. A positive correlation has been reported between water hyacinth and Copper by (Sutton et. al. 1971). A similar type of positive correlation was reported between water hyacinth and Cadmium by (Tokunga et al 1976). (Ghabbour et. al. 2004) isolated the humic acid from the leaves, stems and roots of live water hyacinth plants from the Nile Delta of Egypt and studied the metal binding capacity of the acid. (Musil et. al. 1977) reported concentration of nutrients in various plant parts of water hyacinth.

\section{MATERIALS AND METHODS}

The present study was conducted on Shahpura lake of Bhopal (Latitude: $23^{\circ} 12^{\prime} 00^{\prime \prime} \mathrm{E}$ and Longitude: $77^{\circ}$ 25 ' 30 " N), the capital city of state of Madhya Pradesh, India. The city of Bhopal is also called as 'city of lakes'. A large surface area in Bhopal is covered with lake water and the weed E. crassipes is available in abundance in the city's lakes. Shahpura lake in particular is a sewage fed lake witnessing an over population of the weed. The study was started after having proper survey of the vegetation pattern and predominant aquatic weed species present in the lake. Three different sampling stations were selected keeping in mind population of weed in the lake and polluting points or feeding sources of the lake. They were named as sampling stations 1,2 and 3 respectively. Samples of water hyacinth, surface water and lake sediments were collected from different stations and they were analyzed, as per standard methods in (APHA 1985) and (Hach 1987), using Atomic Absorption Spectrophotometer for the identification of heavy metals. In the present study the concentration of four different heavy metals viz. Lead $(\mathrm{Pb})$, Chromium ( $\mathrm{Cr}$ ), Zinc ( $\mathrm{Zn})$ and Manganese $(\mathrm{Mn})$ in surface water, lake sediments and water hyacinth were studied.

\section{RESULT AND DISCUSSIONS}

A comparison between the concentration of each heavy metal in surface water, lake sediments and water hyacinth is given in the table 1 . The results of study indicate that highest concentration of bioaccumulated $\mathrm{Pb}$ in water hyacinth samples was noted as $74.5 \mathrm{mg} \mathrm{kg}^{-1}$. High concentration of $\mathrm{Pb}$ in the sediments is also reported. According to the USPH (United States Public Health Drinking Water Standards), the permissible limit for Lead $(\mathrm{Pb})$ in drinking water is $<0.05 \mathrm{mg} \mathrm{lit}^{-1}$ (De 2002). In lake water high concentration of $\mathrm{Pb}$ is present which exceeds permissible limits. This suggests that lake water is grossly polluted. The highest concentration of bio-accumulated $\mathrm{Cr}$ in water hyacinth was observed to be $10.8 \mathrm{mg} \mathrm{kg}^{-1}$, whereas in the water samples it's highest concentration was observed to be $0.06 \mathrm{mg} \mathrm{lit}^{-1}$ which is slightly higher as compared to the permissible limit of $0.05 \mathrm{mg} \mathrm{lit}^{-1}$ as per USPH. Cr is believed to be a very toxic metal if present in water bodies as it severely affects the dependent population of aquatic plants and animals. The highest concentration of bio-accumulated $\mathrm{Zn}$ in water hyacinth $61.4 \mathrm{mg} \mathrm{kg}^{-1}$ was noted whereas the highest concentration in sediments was $118 \mathrm{mg} \mathrm{kg}^{-1}$. It shows that $\mathrm{Zn}$ has been accumulated in the aquatic weed to a large extent The highest concentration of bio-accumulated $\mathrm{Mn}$ in water hyacinth were observed to be $929.4 \mathrm{mg} \mathrm{kg}^{-1}$. Higher concentration of $\mathrm{Mn}$ in the macrophtye suggest that $\mathrm{Mn}$ has great affinity towards bioaccumulation in the macrophyte. The results are in accordance with the study conducted on Upper lake of Bhopal which reported the bioaccumulated value of $\mathrm{Mn}$ in the macrophyte in the range 224.33 to $956.5 \mathrm{mg} \mathrm{kg}^{-1}$ (Parashar et. al. 2003). 
Table 1. Table showing concentration of heavy metals in surface water, lake sediments and water hyacinth at three different sampling stations.

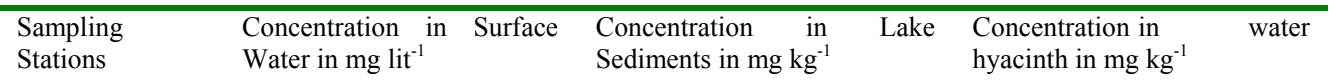

\begin{tabular}{lllll}
\hline Lead & 1 & 0.11 & 198 & 74.5 \\
& 2 & 0.4 & 64 & 56.5 \\
\multirow{3}{*}{ Chromium } & 3 & 0.8 & 159 & 69.7 \\
& 1 & 0.06 & 115 & 10.8 \\
\multirow{2}{*}{ Zinc } & 2 & 0.04 & 44 & 8.5 \\
& 3 & 0.02 & 56 & 39.6 \\
\multirow{2}{*}{ Manganese } & 1 & 0.05 & 118 & 42.9 \\
& 2 & 0.02 & 36 & 61.4 \\
& 3 & 0.06 & 94 & 929.4 \\
& 1 & 0.08 & 678 & 409.6 \\
\hline
\end{tabular}

Of all the heavy metals studied $\mathrm{Pb}, \mathrm{Zn}$ and $\mathrm{Mn}$ tend to show greater affinity towards bioaccumulation. The higher concentration of metal in the macrophyte signifies the bio-magnification that lead to filtration of metallic ions from water (Parashar et. al. 2003). The results of study indicate that the heavy metals are extracted from the polluted water by the weed substantially. It has the capability of extracting even the potentially toxic metals like $\mathrm{Pb}$ and $\mathrm{Cr}$. Thus it can prove to be an innovative and eco-friendly technique for purifying the grossly polluted water bodies.

Conclusion: Water pollution is not only an aesthetic problem, but a serious economic and public health problem as well. Periodical monitoring of the water quality is thus required to assess the condition of surface water of the water bodies around the world and immediate steps should be taken to check the entry of harmful pollutants in the water bodies. This will be helpful in saving the water bodies from heavy metal pollution. The bio-accumulation characteristic of the macrophyte which otherwise is a weed, is helpful in filtration of the metallic contaminants from the lake. Maintaining of proper density of the weed in the water body by way of controlled harvesting followed by disposal may regulate the heavy metal contamination in the lake ecosystem without introducing any foreign chemical substance. The impact of bio-filtration of metals by using weeds is not only a sustainable technique but it is also cost effective with no maintenance.

\section{REFERENCES:}

Ahmed, M. K., Mehedi, M.Y. Haque, M.R. and Ghosh, Ripon Kanti. 2003.

'Concentration of heavy metals in two upstream rivers sediment of the sunderbans mangrove forest, Bangladesh', Asian Journal of Microbiology, Biotechnology and Environmental Science, 5 (1): 41-47.

APHA. 1985. American Public Health Association, Standard methods for the examination of water and waste water, $10^{\text {th }}$ edition, American Public Health Association, Washington D.C.: 391-448.

Bryan, G. W. 1976. 'Heavy metal contamination in the sea.' in : R. Johnston (ed.) Marine pollution, Academic Press, London.

De, A.K. 2002. Environmental Chemistry. $4^{\text {th }}$ edition, New Age International (P) Ltd. New Delhi: 232-272.

Ghabbour, E.A., Davies, G., Lam,Y.Y. and Vozzella, M.E. 2004. 'Metal binding by humic acids isolated from water hyacinth plants (Eichhornia crassipes [Mart] Solm-Laubach : Pontedericeae) in the Nile Delta, Egypt', Environmental Pollution, 131(3) : 445-451.

Hach Company. 1987, Procedures for water and waste water analysis, second edition, Hach company, Loveland, Co: 119.

Holm,L.G., Plucknett, D.L., Pancho, J.V. and Herberger, J.P. 1977. The world's worst weeds: distribution and biology. Honolulu: University Press of Hawaii: 609.

Lowe, W.1970. 'Origin and characteristics of Toxic wastes, with particular reference to the metal industries', Water Pollution control, 69 : 270273. 
Mitchell, D.S. 1976. 'The growth and management of Eichhornia crassipes and Salvinia spp. in their native environment and in alien sitautions' in: Varshney, C.K. and Rzoska, J. (eds), Aquatic weeds in Southeast Asia. The Hague, Dr. W. Junk b.v., Publishers :396.

Moore James.W. and Ramamoorthy, S. 1984. Heavy Metals in Natural Waters: Applied Monitoring and Impact Assessment, SpringerVerlag; New York : 28-246.

Muramoto, S. and Oki, Y. 1983. 'Removal of some heavy metals from polluted water by water hyacinth (Eichhornia crassipes)', Bulletin of Environmental Contamination and Toxicology, $30: 170-177$.

Musil, C.F. and Breen, C.M. 1977. 'The influence of site and position in the plant community on the nutrient distribution and content of Eichhornia crassipes (Marl Solms)', Hydrobiologia, 53: 67-72.

Nor,Y. M. 1990. 'The absorption of metal ions by Eichhornia crassispes', Chemical Speciation and Bioavailability, 2: 85-91.

Parashar,V., Dubey, A., Bajpai, A. and Misra, S.M. 2003. 'Bio-magnification of heavy metals in macrophytes of a tropical wetland', Pollution Research, 22(4) : 569-576.

Pinto,C. L. R., Caconia, A. and Souza, M. M. 1987. 'Utilization of water hyacinth for removal and recovery of silver from industrial waste water', Water, Science and Technology, 19(10) : 89101.
Sculthorpe, C. D. 1967. 'The Biology of Aquatic Vascular Plants'. St. Martin’s Press, New York.

Sivakumar, K., Subbaiah, K. V. and Sai Gopal, D. V. R. 2001. 'Studies of certain trace elements in industiral effluents, sediments and their effect on plant physiology', Pollution Research, 20(1) : 99-102.

Sudhira, H. S. and Kumar, V. S. 2000. 'Monitoring of lake water quality in Mysore city, proceedings of Lake 2000'. International symposium on restoration of lakes and wetlands, 27 - 29 Nov. 2000, CSIC Auditorium, Indian Institute of Science, Bangalore : 1-10.

Sutton, D.L. and Blackburn, R.D. 1971. 'Uptake of Copper by water hyacinth', Hyacinth Control Journal, 9: 18-20.

Tarver, D. P., Rogers, J. A., Mahler, M. J. and Lazor, R. L. 1986. Aquatic and Wetland Plants of Florida. Third Edition. Florida Department of Natural Resources, Tallahassee, Florida.

Tokunga,T., Furuta, N. and Morimoto, M. 1976. Accumulation of Cadmium in Eichhornia crassipes Solms., Eiseikagaku, 22(4) : 234-239.

Vietmeyer, N.D. 1975. 'The beautiful blue devil', Natural History, 84: 64-73.

Wolverton, B.C. \& McDonald, R.C. 1979, 'Water hyacinth (Eichhornia crassipes) productivity and harvesting studies', Economic Botany, 33: 1-10. 